\title{
Neurobiologiczne aspekty duchowości
}

\section{Neurobiological aspects of spirituality}

\author{
Wiesław Dyk ${ }^{\bowtie}$ \\ Uniwersytet Szczeciński, Instytut Filozofii, ul. Krakowska 71-79, 71-004 Szczecin \\ University of Szczecin, Institute of Philosophy \\ 凶wdyk@wp.pl
}

\begin{abstract}
At the core of ethology, Konrad Lorenz's notion of spirituality is identical with the notion of culture. In the context of neuroscience, the gap between the spheres of spirituality and culture is significant; however the spiritual aspect of culture depends on the human spirit. In the context of brain evolutionary processes, the thalamus plays an important role in the shaping of spirituality. Animal and human brain structures and functions show an evolutionary leap between the infraorbital region and the prefrontal cortex, which gives good for searching there for
\end{abstract}

human spirituality. Neuroscientists not only associate human spirituality with brain evolution and development, but also see the foundations of morality and consciousness in its structures. Recent neurobiological research is very insightful into what used to be an exclusively philosophical area of expertise. The considerations presented in the article include language, morality, rationality and mind, in the context of evolution.

Keywords: neurobiology; spiritual brain; evolution; neurobiology of spirituality.

\begin{abstract}
ABSTRAKT
W etologii Konrada Lorenza pojęcie „duchowości” jest synonimem „kultury”. W kontekście neuronauki zdecydowanie zauważa się znaczącą dystynkcję między sferą duchowości a kulturą, chociaż duchowy wymiar kultury zależy od ducha ludzkiego.

W kontekście procesów ewolucji mózgu istotną rolę w kształtowaniu się duchowości przypisuje się wzgórzu. Struktura i funkcja mózgu zwierzęcia i człowieka wykazuje ewolucyjny przeskok
\end{abstract}

między okolicą nadoczodołową a korą przedczołową, co daje podstawę poszukiwania w tych rejonach duchowości ludzkiej. Neuronaukowcy nie tylko wiążą duchowość człowieka z ewolucją i rozwojem mózgu, ale także w jego strukturach dopatrują się podstaw moralności i sumienia.

Słowa klucze: neurobiologia; duchowy mózg; ewolucja; neurobiologia moralności.

\section{WSTĘP}

Emocje są integralną częścią ludzkiego organizmu, a ich aktywność dynamizuje niemalże wszystkie systemy w mózgu. W „M. Tulli Ciceronis Disputationum Libri Quinque” jest mowa o stanie ducha, który określony jest jako adefectus, co współcześnie tłumaczy się jako affectus. W dialogu pada stwierdzenie: „qualis autem homo adfectus esset, talem eius esse orationem" - jaki jest stan ducha człowieka, taka jest jego mowa [1]. Neurobiolog Joseph E. LeDoux w swych badaniach wyraźnie wskazuje, że geneza emocji dokonuje się niezależnie od racjonalności. Jednakże w mózgu ludzkim emocje i myśli łączą się ze sobą, dając podstawę tworzenia się duchowości.

Autor niniejszej pracy duchowości nie pojmuje tak jak współcześni teolodzy duchowości. Duchowość w tym układzie jest naturalnym, ewolucyjnym stadium genezy homo sapiens sapiens. Wykazuje to LeDoux w kontekście neurobiologii oraz w aspekcie ewolucji (gdyż wiadomo, że ewolucja człowieka jeszcze się nie skończyła). Być może będzie tak, jak on przypuszcza: nastąpi większa symbioza rozumu i emocji. Jest to ewolucyjny kurs ku stadium homo sapientissimus.

W poszukiwaniu podstaw „stanu ducha” współczesnego człowieka autor pozostaje przy określeniu tegoż stanu - podobnie jak LeDoux - za pomocą mózgu emocjonalnego. Ewolucja neocortex w mózgu człowieka - z uwzględnieniem jego systemowego związku z ukształtowanymi uprzednio strukturami i funkcjami emocjonalnymi - daje wielkie szanse rozwoju duchowości człowieka. W tym rozwoju nie należy jednak dyskredytować emocji, gdyż u podstaw wchodzą one w proces ewolucyjny homo spirituale lub w aspekcie twórczym - homo creator.

Analizy dotyczące kształtowania się duchowości - w kontekście neurobiologii - odnoszą się do nomenklatury Lorenza w pewnym sensie utożsamiającego pojęcie „duchowości” z pojęciem „kultury”. W odniesieniu do wcześniej rozwiniętych struktur mózgowych gatunek ludzki już posiadał wrodzone reakcje emocjonalne na pojawiające się bodźce, ale to nie różniło go jeszcze od zwierząt. Do tego stadium można mówić o tworzonej przez człowieka kulturze. Jednakże ewolucja neorcotex dała możliwość genezy samorefleksji. Wykształciły się w tym procesie już bardzo zorganizowane struktury umożliwiające zajęcie kreatywnej postawy w przyrodniczym środowisku. 
Fakt ten świadczył o wyjątkowości człowieka w ożywionym świecie. Właśnie na tym etapie ewolucji Lorenz mówi o duchowości gatunku ludzkiego.

Istotną rolę w procesie zmierzającym ku duchowemu stadium (zresztą poprzednio także) odgrywały tzw. fulguracje. Istotną cechą fulguracji jest zintegrowanie na wyższym poziomie struktur, które uprzednio funkcjonowały niezależnie na niższym poziomie [2].

Zdobywana w procesie filogenetycznym wiedza dawała podstawę przebudowania ludzkiego mózgu. Na uwagę zasługuje powstanie myślenia w kolejnej fulguracji [2]. Tak więc w procesie kulturowym, w filogenezie, wykształciły się normy ludzkiego zachowania.

Poświęcenie wiele miejsca etologii, gdy temat artykułu odsyła do neurobiologii, uwarunkowane jest tym, że Lorenz negatywnie przewiduje przyszłość powstałej ludzkiej kultury i ludzkiego ducha. Ani obecna kultura, ani też współczesna duchowość nie dają nadziei na dalszy rozwój życia gatunku ludzkiego na Ziemi. Lorenz twierdzi, że „postępujący upadek naszej kultury ma, w sposób tak oczywisty, charakter patologiczny, nosi tak oczywiste cechy choroby ludzkiego ducha (...) potrzebny jest przyrodoznawczy wgląd w przyczyny tych patologicznych zjawisk" [2]. W podjętej kwestii Lorenz nie tylko oczekuje, ale nade wszystko domaga się zburzenia muru dzielącego nauki przyrodnicze od nauk humanistycznych. Konsekwencją zburzenia muru będzie zainteresowanie się przyrodników światem wartości, a humaniści wyzwolą się z kajdan idealizmu. Musi ustąpić przekonanie, że człowieka można zrozumieć tylko w kontekście nauk przyrodniczych.

W zamiarze autora próba sięgnięcia do neurobiologii kierowana jest zamiarem dania choćby niewielkiego przyczynku do wykazania możliwości ocalenia prawdy o człowieku. Ojciec etologii zresztą żywi nadzieję, że to nastąpi; prawda zwycięży, ale kiedy przyjdzie na to czas. Rozwijające się neuronauki dają wielką nadzieję na to, że prawda rychło zostanie odkryta i czas zwycięstwa nadejdzie. Ewolucja jakby celowo prowadzi do zbawczej mety zwycięstwa. Dokonuje się to przez rozwój świadomości, języka, moralności i wreszcie osiągnięcia doskonałości duchowej.

\section{GENEZA EMOCJI I JĘZYKA}

Od Ducha Świętego otrzymał łaskę przemawiania w językach

(Orygenes)

Joseph E. LeDoux uważa, że w celu zrozumienia natury emocji najlepiej jest potraktować je jako biologiczne funkcje układu nerwowego, tzn. jako funkcje mózgu. Strukturę mózgu zaleca on pojmować jako konsekwencję ewolucji w określonych warunkach środowiska. Gdy powstała u ssaków nowa kora (neocortex), wyłoniły się wyższe funkcje psychiczne, jak myślenie, umysł i rozumowanie. Jest prawdą, że maksymalny rozwój tych funkcji nastąpił u Homo sapiens sapiens. Jeśli natomiast chodzi o emocje, to - chociaż nie wszystkie mózgi są takie same - u wszystkich ssaków nerwowa organizacja, będąca podstawą zachowań emocjonalnych, jest taka sama lub bardzo podobna. Chociaż mózg w dalszym ciągu podlega ewolucji, to jednak struktury odpowiedzialne za zachowania emocjonalne już od pewnego czasu nie podlegają zmianom. W „neurobiologii duchowości” warto zatem zwrócić szczególną uwagę na kształtowanie się emocjonalnej struktury i funkcji po utworzeniu się kory mózgowej.

Jerzy Vetulani w artykule pt. „Mózg i świadomość” podaje, że ewolucja mózgu „od rekina do człowieka trwała ok. $400 \mathrm{mln}$ lat” [3]. Jednakże powstanie neocortex ok. 3 mln lat temu umożliwiło ugruntowanie się 2 funkcji mózgu, tj. emocji i rozumu. Ośrodki emocji lokują się w strukturze podkorowej, tj. hipokampie, jądrze migdałowatym i podwzgórzu (tu są ośrodki emocji, przyjemności, nastrojów i motywacji). Kora mózgowa, a szczególnie kora przedczołowa, stanowi mózg racjonalny (myślenie, przewidywanie, intelekt). W tak powstałym i funkcjonującym mózgu procesy zmysłowe oraz świadomość przebiegają przez wzgórze i stanowią fundament - jak pisze Vetulani - wyrażania się duszy [3].

Zwierzęta i człowieka dzieli ewolucyjny przeskok między powstałymi strukturami podczołowymi oraz korą przedczołową i to stanowi bardzo wielką różnicę między światem zwierząt a Homo sapiens. W tym aspekcie Vetulani wymienia tutaj [3]:

1. Różnicę wymiarów mózgu i współczynnik umózgowienia (stosunek masy mózgu do masy ciała.

2. Przekształcenie się starych struktur w nowe obszary w mózgu człowieka, np. nowe podregiony w ludzkiej korze śródwęchowej.

3. Powstanie kory przedczołowej jako centrum wykonawczego mózgu (the central executive), które u człowieka stanowi $29 \%$ powierzchni całego mózgu (np. u szympansa 17\%, a u makaka $11,5 \%$ ).

4. Powiększenie struktury i ulepszenie kory przedczołowej, co związane było ze zmniejszeniem się innych obszarów korowych, np. kory wzrokowej (np. u makaka stanowi ona $17 \%$, a u człowieka 1,5\%).

5. Pojawienie się asymetrii płaszczyzny skroniowej w obszarze skroniowym związanym z mową u ludzi. Pomimo że w mózgu małp istnieje odpowiednik ośrodka słuchowego Wernickiego (jest lepiej rozwinięty w lewym przednim obszarze skroniowym) i ośrodka ruchowego mowy Broki, to jednak - ze względu na istnienie symetryczności w płaszczyźnie skroniowej - małpy mające możliwość mowy mogą używać tylko gestykulacji oraz języka symbolicznego.

6. Mowę artykułowaną, wokalizację u człowieka umożliwiły: asymetryczność w płaszczyźnie skroniowej oraz powstanie tzw. skrzynki głosowej. Rozwój czaszki przyczynił się do utworzenia więcej miejsca w szyi, co sprzyjało pomieszczeniu struktur anatomicznych odpowiedzialnych za mowę artykułowaną.

Z punktu widzenia anatomii krtań człowieka umieszczona jest głęboko w gardle i jama ustna jest większa, co bardziej umożliwia artykulację różnych dźwięków. Unerwiona muskulatura języka umożliwia planowanie, szybkie kontrolowanie oraz 
wykonywanie precyzyjnych ruchów w dokładnym i płynnym generowaniu słów. Oprócz tego ludzie wydobywają głosy przy wydechu, a zwierzęta wydają odgłosy przy wdechu i wydechu [4].

7. Komunikacja słowna między ludźmi czyni człowieka nieporównywalnym ze światem zwierząt [5].

8. Nastąpiło rozległe i swoiste unerwienie dopaminergiczne, co umożliwia w obszarach neocortex selektywną ekspansję zróżnicowaną w procesie ewolucji.

Wydawałoby się, że narzuca się teza, iż rozwój późniejszych struktur mózgu, tj. związanych z mową i inteligencją, jest przeskokiem ewolucyjnym do nowego świata Homo sapiens sapiens. Jednak LeDoux - wbrew kognitywistom - podaje, że umysł bez emocji trudno nazwać umysłem, bez emocji trudno też mówić o świadomości. Emocja jest pewnym rodzajem myślenia [6]. Podobnie Vetulani wykazuje, że między reakcjami emocjonalnymi i racjonalnymi odpowiedziami poznawczymi istnieje obustronny związek za przyczyną regulacji językowej. Posługując się językiem, można złagodzić reakcje emocjonalne, ale też operując językiem, można wzbudzać emocjonalnie słuchaczy [7].

Bliskości człowieka i zwierzęcia można dopatrywać się w tym, że emocje są sercem ich duszy. Nie tyle rozum i język odgrywają tu istotne znaczenie, ile emocje utworzone na poprzednim stadium ewolucji. Według LeDoux dusze ludzi i zwierząt, w kontekście neurobiologii, rozumiane są jako twory emocjonalne. W aspekcie analiz neurobiologicznych dusze zwierzęce są emocjonalnie zdeterminowane $\mathrm{w}$ dążeniu do zachowania życia. U człowieka natomiast sfera duchowa uwzględnia zarówno emocje, jak i argumenty racjonalne, czyli w swych decyzjach i w działaniu dusza znacznie wykracza poza sferę biologiczną i psychologiczną. Z punktu widzenia przyrodniczego jednakże to, co jest tworzone w kontekście myślenia abstrakcyjnego, zdolności poetyckich i matematycznych, działań, nie ma żadnego związku, jak podaje LeDoux, z ochroną przed grożącymi niebezpieczeństwami i dążeniem do przetrwania.

Bez języka, jak twierdzi Peter Gärdenfors, możliwe są różne funkcje umysłowe. Jednakże brak samoświadomości oraz bogatego świata wewnętrznego uniemożliwia rozwój języka [8] „Język jest potężnym narzędziem ujawniania się tego, co dzieje się w naszych głowach" [8]. Eksternalizacja świata wewnętrznego stała się możliwa we wspólnocie tworzenia kultury i życia w kulturze. Konieczne zatem wydaje się przedstawienie argumentów przemawiających za sensem życia i moralnego zachowania w kontekście ewolucyjnym. Moralność domaga się uwzględnienia tego, co dzieje się w naszych głowach, a więc umysłu.

\section{WOKÓŁ EWOLUCJI UMYStU I MORALNOŚCI. PRZEGLĄD STANOWISK}

Cnoty moralne sq zakorzenione w ludzkiej naturze (św. Tomasz z Akwinu)

Michael Tomasello podjął wysiłek poszukiwania źródeł genezy „myślenia ludzkiego” w kontekście ewolucyjnym i doszedł do stanu sceptycznego. W końcu stwierdza, że nie może doszukać się wcześniejszych form behawioralnych, z których - w ramach mutacji i selekcji - można wyprowadzić zaistniałe ludzkie stadium rozwoju. Stwierdza zatem, że poznanie i myślenie ludzkie pojawiło się przypadkiem [9]. Różnorodność i zmienność środowiska stwarzała nowe szanse i nowe zagrożenia, musiał więc pojawić się umysł, który dawał szansę rozeznania zaistniałej, konkretnej sytuacji i szukania ocalenia.

Inaczej niż Tomasello, Michael Gazzaniga wykazuje deterministyczne podejście do genezy i funkcjonowania ludzkiego mózgu. Mózg jest skutkiem ewolucji z przyrodniczego fundamentu, tj. chemicznego i fizycznego. $\mathrm{Z}$ tego też względu logiczną konsekwencją są później powstałe struktury i funkcje mózgowe. Determinizm istniejący w fizyce stanowi rację deterministycznego podejścia w wyjaśnianiu w neurobiologii [10]. Determinizm neurobiologiczny przejawia się w tym, że mózgi w istniejących warunkach fizykalnych działają deterministycznie $[11,12]$. Skoro tak, to jak człowiek może być odpowiedzialny za swe decyzje i podjęte działania? Gazzaniga deterministycznie określa funkcjonowanie mózgu w konkretnej sytuacji społecznej. Umowa społeczna ustala relacje między jednostkami i w ramach tych ustaw deterministyczny mózg może podejmować wolne i świadome decyzje, a więc jest za te decyzje odpowiedzialny.

Zewnętrzne warunki fizyczne i prawa przyrody ze swej natury determinują nie tylko ludzkie zachowanie, ale także i jaźń. Jednakże zdeterminowany świat i umysł będący wytworem procesów fizycznych w mózgu, zdaniem Gazzanigi, nie może ograniczać wolnych wyborów i ludzkiej odpowiedzialności. Zagadnienie to Gazzaniga podejmuje w książce pt. „Kto tu rządzi - ja czy mój mózg? Neuronauka a istnienie wolnej woli" [13]. Stwierdza, iż źródła odpowiedzialności należy się dopatrywać w relacjach z innymi ludźmi, w sposobie zachowania się w otoczeniu, a nie w mózgu [13]. Człowiek jest istotą mającą wolną wolę, jest niejako wpisany, zatopiony w swym życiu, w świat, w którym żyje, w swym trwaniu i rozwoju zależny jest od kontekstu społecznego. Nie tylko uwarunkowania fizykalne i biologiczne, ale także - a może nade wszystko kulturowe i społeczne umożliwiają mu zyskanie nowej cechy, tj. wolności, tożsamości osobowej w otaczającym go świecie, wśród ludzi i wynikającej stąd odpowiedzialności.

Mózg w procesie ewolucyjnym został ukształtowany z różnych wyspecjalizowanych modułów, w znacznej mierze zdeterminowanych genetycznie, jednakże podlega dowolnemu kształtowaniu w trakcie ontogenezy [13] . „Między modułami nie istnieją relacje hierarchiczne" [13]. Funkcjonowanie mózgu cechuje współdziałanie między poszczególnymi jego strukturami. Nie jest możliwe obecnie odszukanie globalnego systemu sterującego mózgiem. Możliwość kształtowania się i ewolucyjne wyspecjalizowanie struktur i funkcji mózgu naczelnych zapewniło człowiekowi przewagę w zmieniającym się środowisku. Podstawą tego jest fakt, iż sieciowa struktura mózgu u naczelnych daje mu wielką sprawność w przetwarzaniu danych oraz szybką komunikację w ramach sieci globalnej.

Szczególnie w trzecim rozdziale swej książki „Kto tu rządzi” Gazzaniga uzasadnia tezę dotyczącą jedności wewnętrznej 
i tożsamości osoby ludzkiej. Odwołuje się do teorii lewopółkulowego interpretatora. Lewa półkula mózgu dominuje w porządkowaniu ex post z otrzymywanych wcześniej doznań i opierając się na nich, automatycznie oraz nieświadomie tworzy historię osobowości [13].

Pomimo że Gazzaniga nie odnosi się wprost do religii, podjęcie zagadnień poznania, wolności woli, umysłu, świadomości, odpowiedzialności i tożsamości osobowej otwiera możliwą dyskusję wokół natury ludzkiej i jej uwarunkowań religijnych.

Po zaprezentowaniu badań i wynikających z nich konsekwencji Gazzaniga w czwartym rozdziale swej książki dochodzi do wniosku, że nic nie przeszkadza, by w deterministycznym świecie opowiedzieć się za kompatybilizmem, czyli uznać istnienie wolnej woli. Przeciwnie, inkompatybiliści stojąc na rozdrożu: determinizm czy wolna wola, opowiadają się przeciw istnieniu wolnej woli. W społeczności powstają interakcje między osobami, a więc konieczny jest nowy zbiór zasad umożliwiający wspólnotowe współżycie [13]. Wolność i odpowiedzialność są fundamentem emergencji tychże zasad i jednocześnie umysłu społecznego. Umysł społeczny jest podstawą kształtowania się empatii oraz moralności.

Michael S. Gazzaniga w książce pt. „O tajemnicach ludzkiego umysłu. Biologiczne korzenie myślenia, emocji, seksualności, języka i inteligencji” [14] wyjaśnia genezę świadomości w przyrodzie. Podaje, że „stan umysłowy jest świadomy, o ile jest coś takiego jak poczucie, jak to jest być w stanie umysłowym. Inaczej mówiąc, stan umysłowy jest świadomy, jeżeli wiąże się z poczuciem jakościowym - z odnośną jakością przeżycia" [14]. Przy zawieszeniu poprawności redukcyjnego podejścia w eksplanacji świadomości dochodzi do wniosku, że „własności biologiczne superweniują na własnościach fizycznych. Ogólnie rzecz biorąc, superweniencja jest relacją między dwoma zbiorami własności: zbiorem własności typu B - czyli, intuicyjnie ujmując, własności wysokiego poziomu - i zbiorem własności typu A - czyli bardziej podstawowych własności niskiego poziomu" [15]. Oczywiście istnieje pytanie bez odpowiedzi: dlaczego w procesie ewolucji powstały „istoty świadome, a nie zombie” [15]. Rozumowanie, że z systemów fizycznych wyłoniła się świadomość, byłoby słuszne po przyjęciu tezy: „Gdyby tylko Bóg (hipotetycznie) ustalił wszystkie fakty w naszym świecie, fakty biologiczne (świat - przyp. D.W.) dostałby gratis" [15]. Potrzebna jest zatem nadprzyrodzona ingerencja w redukcyjnej procedurze wyjaśniania. Autor zdaje sobie sprawę z tego, że powstanie świadomości oraz ludzkiego myślenia „zawsze pozostanie niewyjaśnione w ramach ujęcia fizycznego. Wyjaśnienia świadomości musimy więc szukać gdzie indziej. Z pewnością nie należy z niego rezygnować; musimy jedynie porzucić wyjaśnienie redukcyjne. Możliwość nieredukcyjnego wyjaśnienia świadomości pozostaje otwarta" [15].

Myślenie i język słowny jednak wyróżnia człowieka z naczelnych oraz jasno wskazuje, że wygenerowana moralność wytycza cel trwania we wspólnocie i temu celowi muszą być podległe inne możliwe cele życia. Tak więc relacje we wspólnocie domagały się wolności i przestrzegania zasad etycznych. Wybór czynu nie był zatem dyktowany osobistymi oczekiwaniami. Nadrzędne cele musiały ścierać się z bieżącymi możliwościami i egoistycznymi pragnieniami. Peter Gärdenfors ukazuje, jak w kontekście ewolucyjnym następowała eliminacja chęci działań egoistycznych chociaż na krótką metę. Prowadzi to do tzw. dylematu więźnia, tzn. brak współpracy jednostek we wspólnocie prowadzi do pogorszenia się życia wszystkich. „Takie emocje jak wstyd i miłość oraz takie wartości społeczne jak zaufanie i uczciwość wyłoniły się na drodze procesów ewolucyjnych, aby powstrzymać nas przed sięganiem po krótkofalowe zyski wynikające z dylematu więźnia" [8]. Podaje on, że uczucia i popędy biologiczne mogą prowadzać do konfliktu we wspólnocie i w kulturze, stąd wyprowadza wniosek, że moralność nie jest w pełni uwarunkowana biologicznie [8].

\section{MIĘDZY NAMIĘTNOŚCIĄ A RACJONALNOŚCIĄ}

Prawda i dobro osiagalne sq uczuciem i wolq (św. Augustyn)

Błażej Pascal odróżnił wiedzę serca od wiedzy rozumu i tej pierwszej przyznał większe znaczenie, bo „serce ma swoje racje, których rozum nie zna" [16]. Podjęcie zagadnienia emocji automatycznie kieruje rozum ku sercu. Tak czyni m.in. Goleman, który w książce pt. „Inteligencja emocjonalną” pisze: „Snując rozważania, dlaczego ewolucja wyznaczyła emocjom tak centralną rolę w ludzkiej psychice, socjologowie wskazują na przewagę porywów serca nad wskazaniami rozumu (...). Powiadają oni, że emocje kierują nami wtedy, kiedy mamy stawić czoła zadaniom i wyzwaniom zbyt ważnym, aby zmierzenie się z nimi pozostawić samemu rozumowi. (...) Każdy pogląd na naturę człowieka, który ignoruje potęgę emocji, jest bardzo krótkowzroczny" [17].

W ewolucyjnej perspektywie powstałe i ciągle organizujące się struktury neurobiologiczne działały najlepiej, nawet eksplozja demograficzna i rozwój technicznej cywilizacji tylko nieznacznie odcisnęły się „na naszych biologicznych szablonach życia emocjonalnego" [17].

Daniel Goleman nie neguje wartości rozumu kosztem wykazywania roli emocji w życiu człowieka. Podkreśla jednak, że kwestia umysłu domaga się uwzględnienia, w tej samej mierze, emocji i racjonalności. Umysł ludzki cechuje dwuaspektowość: istnieje umysł serca i umysł rozumu, tj. „umysł emocjonalny", działający czasami impulsywnie i nielogicznie, oraz „umysł racjonalny”, będący świadomym, rozważnym, zdolnym do refleksji i zadumy. Między nimi nie ma przepaści, rozdziału, gdyż funkcjonują na ogół w harmonii, chociaż sposoby poznawania przez nie rzeczywistości dokonują się na innych drogach i stanowią niezależne władze. Zdarza się, że umysł racjonalny w niektórych sytuacjach nie poddaje się emocjonalnym bodźcom, ale bywa i tak, że zostaje przez umysł emocjonalny przyćmiony, przytłoczony [17]. W każdej sytuacji, ogólnie mówiąc, „umysł ludzki” wiąże się z dynamiką działania umysłu emocjonalnego i umysłu racjonalnego. 
Trudno mówić o racjonalności, gdy odrzuca się emocjonalność. Najpierw, pod względem ewolucyjnym, z pnia mózgu wyłonił się umysł emocjonalny (ośrodki emocjonalne). Najstarszym jest zmysł powonienia (głównymi częściami węchomózgowia są hipokamp i ciało migdałowate). Dopiero później, na jego podłożu (czyli na układzie limbicznym i później ukształtowanych warstwach mózgu emocjonalnego), utworzył się umysł racjonalny, tj. nowa kora (neocortex). Ta ostatnia część umożliwiła przetrwanie w zmieniających się warunkach oraz tworzenie kultury i cywilizacji. Umysł racjonalny nie wyparł umysłu emocjonalnego na poziomie ewolucji naczelnych, ale umożliwił powstanie różnorodnych i większego zakresu reakcji emocjonalnych [17].

W znacznym stopniu emocji u ludzi należy doszukiwać się w ciele migdałowatym, blisko podstawy kręgu limbicznego. „Ciało migdałowate i wzajemne oddziaływania zachodzące między nim a nową korą mózgową tworzą rdzeń inteligencji emocjonalnej" [17]. Ciało migdałowate wytwarza reakcje emocjonalne górujące nad rozsądkiem, a nawet nie dopuszcza sygnałów płynących z kory. Kiedy reakcje emocjonalne płyną do ciała migdałowatego ze wzgórza z pominięciem kory, to wspomnienia i reakcje ciała migdałowatego są zapamiętywane i mogą być nieświadomie odtwarzane.

Ocena reakcji emocjonalnych dokonuje się w korze, tzn. gdy bodziec z narządów zmysłowych wysyłany jest przez wzgórze do kory, z wyjątkiem węchu. W płacie czołowym reakcje są rejestrowane i analizowane, emocje są uwzględniane tylko w kwestiach krytycznych. Goleman, wspierając się osiągnięciami LeDouxa, podaje, że „głównym wyłącznikiem niepokojących emocji wydaje się być przednia część lewego płata czołowego. (...). Przednie części prawego płata czołowego są siedliskiem uczuć negatywnych, takich jak strach czy agresja, natomiast lewy płat utrzymuje te surowe emocje w ryzach, prawdopodobnie hamując działanie płata prawego" [17]. Teraz można wskazać neurobiologiczną współpracę lub jej brak między umysłem emocjonalnym i umysłem racjonalnym. Nie w korze, lecz w drogach łączących ciało migdałowate z korą mózgową następuje współpraca albo rywalizacja między rozumem a sercem. Zwycięstwo nie zawsze jest po stronie rozumu. „Mózg myślący pełni kierowniczą rolę w stosunku do emocji, z wyjątkiem owych chwil, kiedy emocje wyrywają się spod jego kontroli i rządzić nami zaczyna mózg emocjonalny" [17]. Dochodzi w konsekwencji do sytuacji, w której umysł emocjonalny determinuje umysł racjonalny do usprawiedliwienia zachowań emocjonalnych i tworzenia argumentacji racjonalnych podjętych decyzji i czynów [17].

Konsekwencją narzucającą się z powyższych analiz jest kształtowanie umysłu emocjonalnego oraz umysłu racjonalnego. Jednakże nie tylko. Uwzględnienie podstaw osiągnięć neurobiologicznych w odniesieniu do Homo sapiens i Homo affectus daje nadzieję w poszukiwaniu aspektu kształtowania się Homo religiosus lub Homo spiritual lub też Homo creator, a więc jego religijnej duchowości. W analizach swych autor posłużył się propozycją Denyse O’Leary oraz Mario Beauregarda w książce pt. „Duchowy mózg” [18].

\section{GENEZA DUCHOWOŚCI W KONTEKŚCIE MÓZGU EMOCJONALNEGO I RACJONALNEGO}

Gratia non tollit naturam, sed eam supponit et perficit (św. Tomasz z Akwinu)

Już na początku tego rozdziału należy powiedzieć, że autorzy książki „Duchowy mózg” w prezentacji swej tezy wyraźnie występują przeciw ujęciom zarówno niematerialistycznym, jak i materialistycznym, a m.in. przeciw podejściom: biologii ewolucyjnej, psychologii ewolucyjnej, autotranscendencji genetycznej (w tej kwestii, krytyce została poddana teza genetyka D. Hamera, że posiadamy gen Boga VMAT2 w dwóch wersjach [18]), tzw. kasku Bożego (stymulacja mózgu polem magnetycznym), idei memopleksu - w rozumieniu Dawkinsa, neuroobrazowania metodami funkcjonalnego rezonansu magnetycznego, pozytonowo-emisyjnej tomografii komputerowej i elektroencefalogramu w stanach skupienia, modlitwy.

Autorzy książki „Duchowy mózg” skupiają się na koncepcji przeżycia z pogranicza śmierci (Near Death Experience - NDE) i doświadczenia religijnego, duchowego i/lub mistycznego (DRDM) z pogranicza życia i śmierci (śmieci klinicznej). Badania te wykorzystują ateiści, by udowodnić, że powstałe wizje i doświadczenia są wynikiem pracy mózgu.

Inne jest podejście O'Leary’ego i Beauregard. Można już na początku powiedzieć za autorami, że religia nie jest tożsama z funkcjami mózgu, jak również nie jest „artefaktem mózgu" [18]. Teza ta jest uzasadniona w prezentowanej książce.

Sprawa jest dla autora interesująca, gdyż z jednej strony jest ewolucjonistą, a z drugiej strony - doznał śmierci klinicznej. Uzasadnienia możliwości bezpośredniego kontaktu osoby z duchową: Siłą, Rzeczywistością, Osobą są szerokie, poprawne i konsekwentne. Podjęta - w tym kontekście - przez O’Leary'ego i Beauregard krytyka ujęć psychologii ewolucyjnej jest w mniemaniu autora do zaakceptowania. Religia przecież nie stanowi produktu ubocznego ewolucji biologicznej, ekonomicznej i kulturowej. Kwestia roli genetyki i magnetoterapii w genoteologii i magnetoteologii powinna, jeśli jest to możliwe, wykazywać zasadność swych idei. Koncepcje NDE oraz DRDM, mimo że są posądzane i przedstawiane jako subiektywistyczne, to w kontekście neuronauki są godne analizy. Jest to o tyle wartościowe, że O'Leary i Beauregard wskazują na jej zgodność z logiką badań naukowych i wymogami metodologicznymi określonymi przez K.R. Poppera (falsyfikacja), powszechnie przyjmowanymi w praktyce badawczej. Przeżycia i doznania stanu śmierci klinicznej przekazał także neurochirurg uprzednio sceptyk - Eben Alexander [19]. Przekazu Alexandra i własnych doznań ze stanu śmierci klinicznej autor nie włącza do podjętych analiz w niniejszym artykule. Natomiast warto się odnieść do neurobiologicznej argumentacji tezy istnienia duszy w książce „Duchowy mózg”. Doświadczenie religijne, duchowe i/lub mistyczne (DRDM) nie może stanowić produktu ubocznego „architektury poznawczej” mózgu wbrew pozytywistycznym poglądom. Mózg nie jest kreatorem doznań duchowych ani też nie stwarza Boga [19]. W mózgu jednak odzwierciedlają się doznania duchowe z transgresyjnego poziomu. 
Doświadczenia wiary wyjaśniane są w kontekście systemu religijnego, ale też podlegają analizom naukowym. Lewandowska-Ronnengren z Karolinska Intituet w Szwecji na łamach popularno-naukowego czasopisma „Wiedza i Życie” podaje że mózg jest ewolucyjnie przystosowany do poszukiwania i odbioru doznań duchowych [20]. W swej strukturze mózg jest ewolucyjnie przygotowany do odczuwania duchowości. „Układ limbiczny odpowiada za pozytywne i negatywne emocje, motywację oraz przywiązanie, a jego aktywność wiązana jest z odczuwaniem doznań religijnych. Istotną rolę odgrywają w tym hipokamp, który odpowiada przede wszystkim za pamięć, a zmiany jego funkcjonowania mogą powodować halucynacje, oraz ciało migdałowate. (...) Hipokamp i ciało migdałowate w połączeniu z płatem skroniowym umożliwiają ludziom przeżywanie doświadczeń mistycznych" [20].

Duchowość człowieka jest faktem, ale nie ma podstaw do zredukowania jej do płaszczyzny neurobiologicznej. „Transcendentalny impuls dążenia do kontaktu z Bogiem i światem duchowym jest jedyną z najbardziej podstawowych i potężnych sił obserwowanych u istot z gatunku Homo sapiens sapiens. Z tego właśnie powodu DRDM wskazują na istnienie fundamentalnego wymiaru ludzkiej egzystencji" [20]. Podobne doświadczenia można wykazać u osób, które przeżyły NDE [20]. Logiczną konsekwencją jest uznanie i przyjęcie prawdy, że mózg nie generuje, nie tworzy, ale doświadcza i przekazuje doznane doświadczenia [20].

Z wielkim zainteresowaniem autor doszedł do wniosku, prowadzony argumentacją z poziomu neurobiologicznego, że „śmierć mózgu nie oznacza unicestwienia osoby, czyli likwidacji umysłu, świadomości i jaźni. Poszczególne umysły i osoby wywodzą się z i są połączone z Podłożem Istnienia (pierwotną formą). Jest nią bezczasowy, bezprzestrzenny i nieskończony Duch. (...) Umysł i świadomość to podstawowe i nieredukowalne właściwości Podłoża Istnienia" [20]. Analizy te sięgają do metafizycznych argumentacji fenomenu osoby. Osobą jest Bóg, anioł i człowiek. Bycie osobą, godność osoby ludzkiej oznacza uczestnictwo w Bogu. Człowiek bowiem został stworzony na wzór i podobieństwo Boga. Przyjęta definicja śmierci na podstawie śmierci mózgu nie mieści się w ramach koncepcji osoby ludzkiej. Mimo śmierci mózgu człowiek jako osoba dalej żyje. Jest wiele dyskusji wokół zasadności pobierania narządów do przeszczepów, gdy mózg umarł, ale osoba żyje. W moim przekonaniu (jestem w stanie to uzasadnić w ramach humanitaryzmu) dawstwo narządów dopiero w tym względzie ma humanitarny sens. Jest to żywa i osobowa relacja między dawcą i biorą. Dawca nie daje tego, co mu zbywa, lecz to, co stanowi jego osobową wartość w aspekcie istnienia. Daje szansę istnienia ze źródła ISTNIENIA. Dawstwo organów, po stwierdzeniu śmierci całego mózgu, jest czynem dokonanym z miłości i świadczy jednocześnie o heroizmie. Pierwszy czyn (z miłości) jest powinnością, drugi natomiast (heroiczny) jest całkowicie wolny i niczym nie zdeterminowany. W sytuacji braku możliwości przywrócenia życia po stwierdzeniu śmierci mózgowej analiza zagadnienia, czy wiąże się to ze śmiercią osoby, należy uznać, w kontekście współczesnej neurobiologii, za pozbawione sensu i bezprzedmiotowe.

\section{WNIOSKI}

Koncepcja ewolucji w wyjaśnianiu bioróżnorodności nie wszystkich przekonuje. Tym bardziej odwołanie się do ewolucji w neurobiologii i uzasadnienie, że mózg stwarza Boga, jest nadużyciem. Całkowicie niedopuszczalne jest odwoływanie się do naturalizmu w tłumaczeniu duchowej sfery człowieka i genezy duszy. O'Leary, jako neurobiolog, w wyjaśnianiu przyczynowo-skutkowej genezy duszy ludzkiej podtrzymuje i uzasadnia sceptycyzm wobec analiz mieszczących się w granicach ujęć pozy tywistycznych i naturalizmu. Nie przeczy jednak, by sfera duchowa nie miała związku ze wcześniejszym porządkiem przyrodniczym i nie przejawiała się w porządku natury.

Niniejszy artykuł wskazuje na szerokie pole dynamiki duchowości ludzkiej, tj. języka, moralności, racjonalności i umysłu. Wbrew wszelkiemu podejrzeniu neurobiologia sprowadza człowieka z niebios, by ugruntować go w ziemskiej czasoprzestrzeni - i tutaj źródłem jego dynamizmu i nadzieją rozwoju są emocje, sfera uczuć nadająca sens rozumowi, moralności i słowom. To wszystko ma źródło w naturze. Godność osobowa, fakt istnienia sięga poza granice przyrodzone. Między tymi światami wyraźnie rozpościera się sfera ludzkiej duchowości.

\section{PIŚMIENNICTWO}

1. Mitchell HR, editors. M. Tulli Ciceronis Disputationum Libri QuinqueDougan. Books III-V. Cambridge: University Press; 2015. p. 441.

2. Lorenz K. Odwrotna strona zwierciadła. Próba historii naturalnej ludzkiego poznania. Warszawa: PIW; 1977. p. 55-295.

3. Vetulani J. Mózg i świadomość. In: Prace Komisji Filozofii Nauk Przyrodniczych. T. II. Kraków: Polska Akademia Umiejętności; 2008. p. 39-50.

4. Gärdenfors P. Jak Homo stał się sapiens. 0 ewolucji myślenia. Warszawa: Wyd. Czarna Owca; 2010. p. 242-3.

5. Roth G, Dicke U. Evolution of the brain and intelligence. Trends Cogn Sci 9(5):250-7. doi: 10.1016/j.tics.2005.03.005.

6. LeDoux J. Mózgowe interakcje poznawczo-emocjonalne. In: Ekman P, Davidson R, editors. Natura emocji. Gdańsk: GWP; 2002. p. 191.

7. Vetulani J. Mózg: fascynacje, problemy, tajemnice. Kraków: Wyd. Homini; 2010.p. 52.

8. Gärenfors P. Jak Homo stał się sapiens. 0 ewolucji myślenia. Warszawa: Wyd. Czarna Owca; 2010. p. 201-7.

9. Tomasello M. Historia naturalna ludzkiego myślenia. Kraków: Wyd. Copernicus Center; 2015. p. 215.

10. Gazzaniga M. The Law and Neuroscience. Neuron 2008;60(3):412-5.

11. Gazzaniga M. The Ethical Brain. New York 2005; The Dana Press.

12. tenże, Istota człowieczeństwa. Co sprawia że jesteśmy wyjątkowi, tłum. $\mathrm{z}$ ang. A. Nowak, Wyd. Smak Słowa, Sopot 2011.

13. Ganzzaniga MS. Kto tu rządzi - ja czy mój mózg? Neuronauka a istnienie wolnej woli. Sopot: Wyd. Smak Słowa; 2013. p. 118.

14. Gazzaniga MS. O tajemnicach ludzkiego umysłu. Biologiczne korzenie myślenia, emocji, seksualności, języka i inteligencji. Warszawa: Wyd. Książka i Wiedza; 1997.

15. Chalmers D. Świadomy umysł w poszukiwaniu teorii fundamentalnej. Warszawa: PWN; 2010. p. 31.

16. Pascal B. Myśli. Warszawa: Wyd. Zielona Sowa; 2004. p. 74.

17. Goleman D. Inteligencja emocjonalna. Poznań: Wyd. Media Rodzina; 1997. p. 24-452.

18. O’Leary D, Beauregard M. Duchowy mózg. Neuronaukowa argumentacja za istnieniem duszy. Kraków: Wyd. WAM; 2011. p. 88-446.

19. Alexander E. Dowód. Prawdziwa historia neurochirurga, który przekroczył granicę śmierci i odkrył niebo. Kraków: Wyd. Znak; 2013.

20. Lewandowska-Ronnegren A. Gdzie w mózgu mieszka Bóg. Wiedza i Życie 2017;2(986):62-5. 
